\title{
Postglacial Fault Drilling in Northern Europe: Workshop in Skokloster, Sweden
}

by IImo T. Kukkonen, Maria V.S. Ask, and Odleiv Olesen

doi:10.2204/iodp.sd.11.08.2011

\section{Introduction}

The majority of Earth's earthquakes are generated along plate margins, and the theory of plate tectonics provides the explanation for the occurrence of these earthquakes. However, a minority of earthquakes occurs within continental plates, and the theoretical understanding for these earthquakes is largely lacking (Stein and Mazzotti, 2007). The general assumption is that intraplate earthquakes tend to be relatively small in size. This report summarizes a workshop devoted to a special type of intraplate earthquake-generating faults-postglacial (PG) faults-that so far have been observed only in northern Europe.

Altogether, there are fourteen well-known PG fault structures in northern Sweden, Finland, and Norway with fault scarps up to $160 \mathrm{~km}$ in length and up to $30 \mathrm{~m}$ in height (Figs. 1, 2; Olesen et al., 1992; Lagerbäck and Sundh, 2008; Kukkonen et al., 2010). Assuming that these distinct faults were formed in single events, they would represent earthquakes with magnitudes of up to 7-8 (Bungum and Lindholm, 1997; Kuivamäki et al., 1998). This estimate is supported by numerous observations of massive landslides associated with these structures and dated to have occurred at the last stages of the glaciation. PG faults represent earthquakes with considerable contrast to the present seismic activity in continental northern Europe, where earthquakes are usually smaller than magnitude 4 .

All known PG faults are located in old reactivated zones of weakness in crystalline rocks and are usually SE dipping, SW-NE oriented thrusts. The last major reactivation of these faults is believed to have occurred during the last stages of the Weichselian glaciation ( 9,000-15,000 years B.P.). The earthquakes are believed to have been triggered by the combined effects of tectonic background stresses and rapidly changing stresses from glacial loading by the shrinking Weichselian ice sheet (Johnston, 1989; Wu et al., 1999; Lund, 2005; Lund et al., 2009).

From what is known today, large-scale types of PG faults appear to be restricted in occurrence to northern Fennoscandia. In other previously glaciated areas, such as Canada, postglacial faults are significantly smaller in size (Adams, 1989). Seismological data reveal that the PG faults are currently seismically active, and that small earthquakes are associated with these structures over a significant depth range (down to $37 \mathrm{~km}$ depth; Bungum and Lindholm, 1997; Arvidsson, 1996). They are obviously structures of crustal dimensions and relevance, but not thoroughly understood at the moment (Arvidsson, 1996).

Postglacial faulting has important implications for predicting the behavior of fault zones during future glaciations. Therefore, PG fault research is expected to contribute significantly in planning the disposal of spent nuclear fuel, $\mathrm{CO}_{2}$ and toxic waste into bedrock that currently is prepared in the Nordic countries. Other fields of applied geoscience which may benefit from PG fault research are mineral exploration and estimation of mine stability, as some of the faults are located in areas which host gold, copper, and nickel mineralizations in northern Fennoscandia. Major hydropower and tailing dam complexes may also be influenced by PG faults and their current earthquake activity. An improved understanding of the prevailing in situ stress, erosion, uplift, and sedimentation also has implications for the understanding of offshore petroleum reservoirs on the Lofoten-Barents margin.

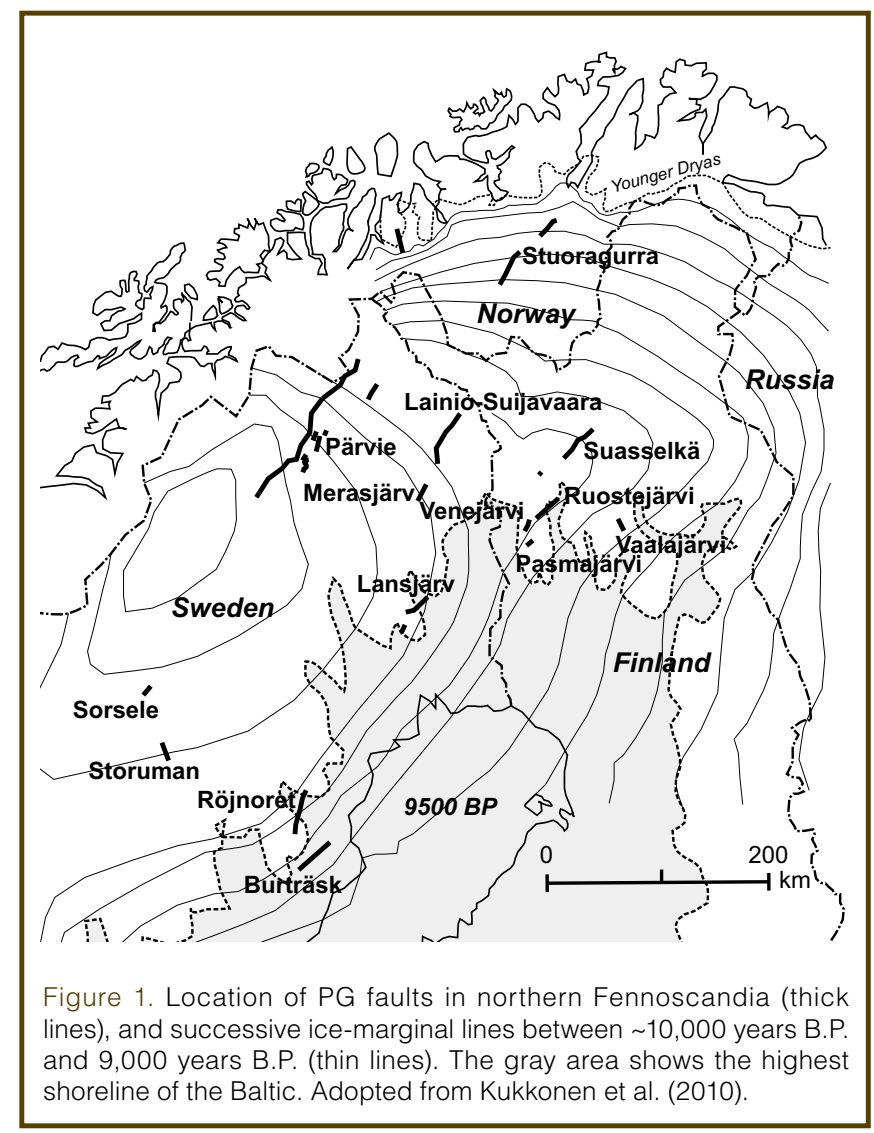




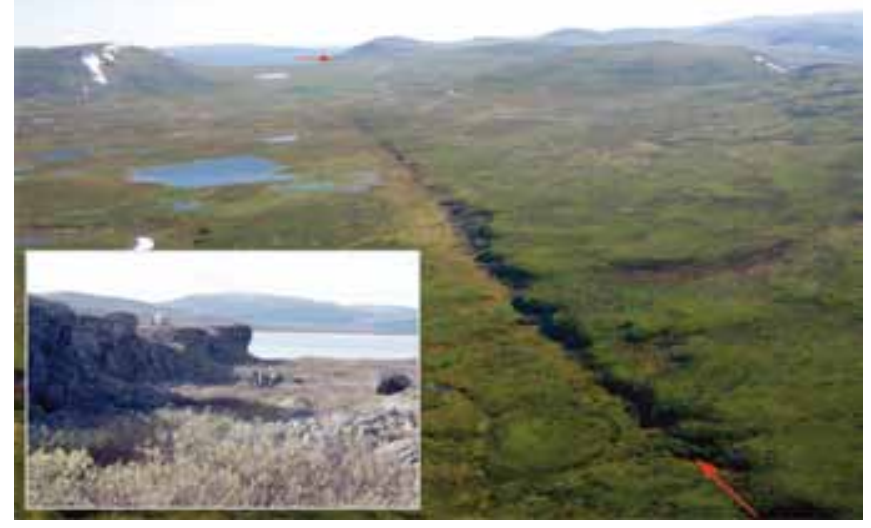

Figure 2. Helicopter view of the southwestern part of the Pärvie PG fault (see Fig. 1 for location). The red arrows show the trace of the fault scarp. The insert shows the fault scarp from the ground surface, about $85 \mathrm{~km}$ to the northeast of the location of the large photo, including a helicopter for scale.

Methods applied in PG fault research so far include bedrock and Quaternary field geology, trenching, seismicity, airborne and ground geophysics, and shallow drilling to about $500 \mathrm{~m}$ (Kukkonen et al., 2010). Revealing the mechanisms and processes related to PG faulting is highly relevant for understanding seismicity in these intraplate areas. Several disciplines and approaches can be used to improve our understanding of PG faults, for example, through earthquake seismology, stress field measurement and modeling, as well as geodetic surface monitoring of fault activity. Scientific drilling and coring is the only way to obtain direct core samples from PG faults at depth, and the resulting boreholes provide direct access to the fault structures for geophysical, hydrogeological, and biological sampling, monitoring and in situ experiments. We organized the ICDP-supported international workshop "Postglacial Fault Drilling in Northern Europe" in Skokloster, Sweden on 4-7 October 2010; thirty-nine participants represented basic research, applied geosciences, industry and authorities from eight countries. At the workshop, the status of PG fault research was discussed, and plans were made towards developing a realistic drilling plan.

\section{Major Scientific Issues/Problems}

The major scientific tasks of PG fault research were identified as follows:

1. What is the tectonic style, deep structure and depth extent of the PG faults?

2. Are PG faults still active?

3. What are the paleoseismic implications of postglacial faults?

4. Did PG faults reactivate more than once? Is it possible to provide quantitative ages of the tectonic systems hosting PG faults?

5. What are the present and paleostress fields and pore pressure of PG faults?
6. How has the faulting affected the rock properties, structure, and deformation in and near the fault surface?

7. What are the hydraulic properties of PG faults, and how did they control fresh glacial meltwater recharge?

8. What is the composition of groundwater (chemistry, salinity, $\mathrm{pH}$, Eh, gas content) in PG faults?

9. Is there a deep biosphere in PG faults?

One of the relevant issues of PG faulting is whether their current appearances really are the result of single earthquake events. The risk and implications of PG faulting to intraplate seismicity in general, and waste disposal repositories in particular, is highly dependent on this. Previous investigations by Lagerbäck and Sundh (2008) suggest that massive landsliding and seismites in soft sediments occurred concurrently with the faulting. They based their arguments mainly on the relatively small erosion of the Weichselian glaciation, and stated that such dramatic faulting which generated the great PG faults in northern Sweden very probably did not occur in glaciations earlier than the Weichselian.

\section{Workshop Discussions}

The workshop presentations can be subdivided roughly into four sub-groups: (1) geology, tectonics, age determination studies; (2) seismic structures, seismicity and other geophysics; (3) stress field, land uplift and plate tectonic forces; and (4) hydrogeology, hydrochemistry, geothermics, and deep biosphere. The participants subsequently discussed the major scientific tasks within these four sub-groups.

The main aim for drilling is to penetrate a fault which presently is seismically active. It is also commonly agreed that it would be useful to compare an active fault with an inactive one. When defining drilling targets it will be important to locate the fault exactly at depth, but this may be difficult. Even in the shallow drilling of the Lansjärv fault in the 1980s, it was not easy to decide where the PG fault actually was because the rock was generally very fractured and broken (Bäckblom and Stanfors, 1989). One of the goals is to drill into the seismogenic zone of a PG fault. Although the macroseismic activity in Fennoscandia seems to be characterized by focal depths of 10-20 km (Ahjos and Uski, 1992; Bungum and Lindholm, 1997), the present seismic activity of PG faults seems to start from surface, at least in the case of the Pärvie fault. The need of seismic monitoring of several faults was considered relevant before the best candidate for drilling can be identified.

A major issue that may be addressed before the start of drilling is if surface studies can reveal whether the fault scarps were formed by one big earthquake or by several smaller ones. Closer inspection of the fault scarps themselves, as well as investigations of the sediment cover using traditional trenching coupled with $14 \mathrm{C}$-dating, would help 
address this question. Bungum and Lindholm (1997) and Kuivamäki et al. (1998) did comparative studies of the relationship between fault length and fault scarp height of PG faults in Scandinavia, and compared the data with recent large earthquakes. Their approach may be pursued to investigate what the scale effect is for the fault (i.e., if there is a relationship between the size of the earthquake and the size of the fault scarp). Furthermore, drill cores would reveal whether there have been paleodynamic weakening effects (thermal pressurization, frictional melting, etc.) related to major periods of faulting in the geological history.

Site survey data that needs to be collected include $2 \mathrm{D}$ and 3D reflection seismic surveys to identify the geometry of PG faults, and passive seismic network data to identify earthquake activity and tomography studies. In addition, ground penetrating radar, 2D resistivity measurements, gravity data, magnetotelluric soundings, and high-resolution topographic surveys with laser scanning (LIDAR) are needed. Drilling of shallow and relatively inexpensive pilot holes may allow characterization and identification of the fault at shallow depths as well as installation of instruments monitoring microseismicity. It is important to expand the seismic surveys and seismic networks to as many of the remaining faults as possible to allow the selection of the best candidates for drilling.

In addition, use of existing data may also improve an ICDP drilling proposal (e.g., synthesizing results on existing cores and their mechanical properties, and reinterpretation of the state of in situ and paleo-stresses). Finally, site investigation data can be utilized to calibrate and improve viscoelastic ice sheet numerical modeling within the site survey areas.

\section{Challenges for Drilling}

Different strategies of drilling geometry were outlined in the workshop. Assuming that drilling takes place on one fault site only, the alternatives would be (1) to drill only shallow $(<1 \mathrm{~km})$ boreholes located on a profile perpendicular to the fault plane, (2) drill one deep borehole $(2-5 \mathrm{~km})$ penetrating the fault at great depth, (3) drill a deep borehole with several shorter boreholes deviating from the main borehole at 1.5-2 $\mathrm{km}$ depth, or (4) combine 1-3 shallow boreholes and a deep $(2-5 \mathrm{~km})$ one. Option no.4 would allow learning while drilling (i.e., modification of drilling plans of the main borehole would be possible from the experience gained in the shallow ones). Such a drilling geometry would also allow cross-borehole experiments and various sampling and monitoring activities in situ and would provide good control of fault properties with depth.

We identified a range of criteria that is helpful to determine the best site for drilling. At the site of drilling, the selected PG fault should (1) be seismically active over a depth interval that can be reached by drilling and beyond;
(2) reveal contrasting geology across the fault to allow unambiguous determination of the fault location; and (3) be a site with good logistics capacity. In addition, pre-drilling investigations should suggest the site has a very good scientific capacity (i.e., the majority of research hypotheses should have a good chance to be tested with drilling).

In order to address the scientific problems, a detailed drilling and testing program needs to be developed. The program should include the collection of oriented cores, borehole logging, fluid sampling, stress measurements, and longterm monitoring of strain/tilt, microseismicity, fluid pressure, and temperature. Preferred core tests include physical properties (petrophysics), rock mechanical determinations, deformation microstructures, mineralogy and geochemistry, and dating. Good quality downhole logging data will be required to allow as complete characterization of the fault as possible, including image logs, density, resistivity/induction, magnetic, full waveforms, and spectral gamma.

After drilling, the most important measurements are stress measurements, strain/tilt and microseismic monitoring, fluid pressure and temperature monitoring, borehole image logging, and geophysical logging. Hydrogeological and microbial studies require post-drilling time for longterm pumping of fluid and gas. Important laboratory investigations include geological logging, petrophysical measurements, rock mechanic testing, and core studies of deformation and fault related microstructures. They also include the capacity to link such data to geochemical studies of the core (e.g., fluid inclusions, if they exist) and geochronology. These data would help improve the models and quality of viscoelastic ice sheet modeling within the site survey area. The possibility for induced seismicity tests should be investigated.

\section{Potential Drilling Targets}

The workshop participants could already identify several potential drilling targets. At the moment the most promising ones would be structures which have long surface scarps, thus indicating crustal scale relevance. The targets should preferably be seismically active, and they should have structures which have been sufficiently imaged with various geophysical techniques. Seismicity has been monitored already in a number of faults with arrays designed for PG faults, but many major faults lack monitoring at the moment. An interesting option would be to compare two structures, one showing seismic activity and one devoid of any activity.

Identification of the scientifically most optimal drilling targets was not possible without more site-specific studies such as seismic arrays to be run for about one to two years. In addition, geodetic monitoring should be started to observe any creep. Previous geodetic leveling and GPS measure- 
ments in Finland (Kuivamäki et al., 1998, Poutanen and Ollikainen, 1995) did not show any measurable movement.

\section{Conclusions and Road Map Forward}

The workshop community considered drilling into PG faults a feasible scientific initiative which would lead to a research project with important societal implications. The present state of the art in PG fault studies is very promising for developing an ambitious new ICDP project "Postglacial Fault Drilling Project” (PFDP).

Many PG faults are seismically active, and they may represent structures which release the current plate tectonic stresses accumulating in the Fennoscandian continental plate. A concept for the project would be to define an active target fault where the preliminary results of seismic monitoring may suggest that the upper parts of the seismogenic zone could be reached with boreholes shallower than about $3 \mathrm{~km}$. The fault would be investigated with both shallow boreholes $(<1 \mathrm{~km})$ and a deep borehole $(\max 2-5 \mathrm{~km})$. Core drilling is essential for a representative sampling of the rocks at least in the expected depth levels of the fault. Furthermore, a combination of several boreholes would allow a variety of downhole experiments, logging, samplings, and monitoring after drilling.

Existing shallow cores (Kukkonen et al., 2010) should be re-examined with modern mineralogical and isotope methods. Pre-drilling science should also include re-analysis of stress field measurements (Bäckblom and Stanfors, 1989; Bjarnason et al., 1989). Pre-drilling science and gathering of site-specific data sets are estimated to take $2-3$ years before a well-defined drilling proposal can be compiled. Meanwhile, information will be disseminated on the PFDP in international conferences, and working group meetings are planned to be organized in association with the EGU and AGU conferences. A session "Intraplate faulting and seismicity with special reference to the Fennoscandian postglacial fault province" is currently arranged at the EGU in Vienna, Austria, in April 2011.

\section{References}

Adams, J., 1989. Postglacial faulting in eastern Canada: nature, origin and seismic hazard implications. Tectonophysics, 163:323-331.

Ahjos, T., and Uski, M., 1992. Earthquakes in northern Europe 13751989. Tectonophysics, 203:1-23.

Arvidsson, R., 1996. Fennoscandian earthquakes: whole crustal rupturing related to postglacial rebound. Science, 274:744-746.

Bäckblom, G., and Stanfors, R., 1989. Interdisciplinary Study of PostGlacial Faulting in the Lansjärv area, northern Sweden, 1986-1988. Swedish Nuclear Fuel and Waste Management Co., Stockholm, Technical Report 89-31.

Bjarnason, B., Zellman, O., and Wikberg, B., 1989. Drilling and borehole description. In Bäckblom, G., and Stanfors, R. (Eds.), Interdisciplinary Study of Post-Glacial Faulting in the
Lansjärv area, northern Sweden, 1986-1988, 7:1-7:14. Swedish Nuclear Fuel and Waste Management Co., Stockholm, Technical Report 89-31, 7:1-7:14.

Bungum, H., and Lindholm, C., 1997. Seismo- and neotectonics in Finnmark, Kola Peninsula and the southern Barents Sea. Part 2: seismological analysis and seismotectonics. Tectonophysics, 270:15-28.

Johnston, A., 1989. The effect of large ice sheets on earthquake genesis. In Gregersen, S., and Basham, P. (Eds.), Earthquakes at North-Atlantic Passive Margins: Neotectonics and Postglacial Rebound: Dordrecht (Kluwer Academic Publishers), 581-599.

Kuivamäki, A., Vuorela, P., and Paananen, M., 1998. Indications of postglacial and recent bedrock movements in Finland and Russian Karelia. Geological Survey of Finland, Nuclear Waste Disposal Research, Report YST-99, 92 p.

Kukkonen, I.T., Olesen, O., Ask, M.V.S., and the PFDP Working Group, 2010. Postglacial faults in Fennoscandia: targets for scientific drilling. $G F F, 132: 71-81$.

Lagerbäck, R., and Sundh, M., 2008. Early Holocene faulting and paleoseismicity in northern Sweden. SGU Research Paper C836, 80 pp.

Lund, B., 2005. Effects of Deglaciation on the Crustal Stress Field and Implications for Endglacial Faulting: A Parametric Study of Simple Earth and Ice Models. Swedish Nuclear Fuel and Waste Management Co., Stockholm. Technical Report TR-05-04, 68 pp.

Lund, B., Schmidt, P., and Hieronymus, C., 2009. Stress evolution and fault instability during the Weichselian Glacial Cycle. Swedish Nuclear Fuel and Waste Management Co., Stockholm. Technical Report TR-09-15, 106 pp.

Olesen, O., Henkel, H., Lile, O.B., Mauring, E., and Rønning, J.S. 1992. Geophysical investigations of the Stuoragurra postglacial fault, Finnmark, northern Norway. J. Appl. Geophys., 29:95-118.

Poutanen, M., and Ollikainen, M., 1995. GPS Measurements at the Nuottavaara Postglacial Fault. Finnish Geodetic Institute, Report 95, 6 pp.

Stein, S., and Mazzotti, S., 2007. Continental intraplate earthquakes: science, hazard, and policy issues. GSA Special Paper 425, Boulder, Colo., (The Geological Society of America, Inc.), $402 \mathrm{pp}$.

Wu, P., Johnston, P., and Lambeck, K., 1999. Postglacial rebound and fault instability in Fennoscandia. Geophys. J. Int., 139:657-670.

\section{Authors}

Ilmo T. Kukkonen, Geological Survey of Finland, Espoo, P.O. Box 96, FI-02151 Espoo, Finland, e-mail: ilmo.kukkonen@gtk.fi.

Maria V.S. Ask, Luleå University of Technology, SE-971 87 Luleå, Sweden.

Odleiv Olesen, Geological Survey of Norway, NO-7491 Trondheim, Norway.

\section{Figure Credits}

Fig. 2: Björn Lund, Uppsala University, Sweden (large photo); and Roger Lagerbäck, Geological Survey of Sweden (insert photo). 